\title{
Kulturní historie sametové revoluce: Revizionistický pohled „zdola“
}

\author{
James Krapfl: Revoluce s lidskou tváří. Politika, kultura \\ a společenství v Československu v letech 1989-1992 \\ Praha, Rybka Publishers 2016, 380 s.
}

Jaký smysl a jaké významy dávali účastníci revolučním událostem odstartovaným v Československu 17. listopadu 1989? Proč se tyto významy vůbec zrodily a odkud se vzaly? Jak se následně prosazovaly, jakým způsobem byly sdíleny, jak motivovaly jednání lidí a jak ovlivňovaly polistopadový vývoj?

Česky, slovensky a mad’arsky hovořící americký historik James Krapfl, působící na kanadské univerzitě v McGillu, se na základě výzkumu pramenů (letáky, petice, bulletiny, prohlášení pracovních kolektivů) snaží v knize Revoluce s lidskou tváři odpovědět právě na tyto otázky. Východiskem je mu kulturní historie. Krapfla proto nezajímá pohled pražských či bratislavských elit, jejichž perspektiva se monopolně prosadila jako oficiální, petrifikovaný a během státního svátku každoročně připomínaný, standardizovaný příběh revoluce. Na elity soustředěný pohled ostatně přinesla dosud nejvlivnější akademická práce Labyrintem revoluce z pera historika Jiřího Suka [2003]. Krapfl se naopak snaží vzkřísit polozapomenuté hlasy revolučních aktérů. Ti vesměs "dělali“" revoluci v regionech. Výsledkem je rekonstrukce odlišných variant téhož revolučního příběhu, důraz na jejich pluralitu a soupeření.

Přitom diskurz sametové revoluce o sobě samé se podle Krapfla začal vyprávět hned během revoluce. A v autorově pojetí nejde o nevinné vyprávění. Příběhy totiž orientují a motivují jednání lidí a to zase formuje mocenské konstelace během politického soupeření. Revolucionáři tedy potřebovali od začátku pojmenovat dění, které se kolem nich odehrávalo a kterého se účastnili. Dávat událostem významy znamená tyto události chápat, interpretovat a zorientovat se v nich, tedy schopnost jednat. Prosazení určitých významů na úkor jiných navíc ovlivňuje převažující jednání ostatních lidí. Snaha prosadit ve veřejném prostoru vlastní definici revoluční situace na úkor jiných definic se proto dostává do centra soupeření. A zůstává tam i nadále, když vysoce zpolitizovaný boj o kolektivní pamět týkající se toho, na co se z roku 1989 vzpomíná, na co se zapomíná a kdo z pamětníků dostává hlas, ovlivňuje i hodnocení a legitimitu polistopadového vývoje a jeho hybatelů.

Jak Krapfl uvádí v první kapitole, nazvané „Rétorika revoluce“ [Krapfl 2016: 29-56 ${ }^{1}$, přičemž totéž strhujícím způsobem diskutuje v závěru [s. 269-282],

${ }^{1}$ Dále jsou odkazy na recenzovanou knihu uváděny pouze čísly stránek v hranaté závorce.

(C) Sociologický ústav AV ČR, v.v.i., Praha 2018 
každý příběh lze vyprávět čtyřmi základními způsoby: jako romanci, komedii, tragédii a satiru. Zde autor vychází z klasického literárněvědního konceptu Northropa Frye publikovaného v knize Anatomie kritiky: čtyři eseje [1957, česky 2003]. A zároveň polemizuje s kulturně-historickou analýzou Velké francouzské revoluce z pera Lynn Huntové s názvem Francouzská revoluce. Politika, kultura, třída [1984, česky 2007], podle níž se během revoluce ve třech fázích postupně prosazují tři odlišné narace: komedie, romance a tragédie. Avšak podle Krapfla se ve francouzském př́ípadě nejprve prosadila romance a poté převládla rétorika komedie, obě narace nicméně přežívaly vedle sebe. Také $\mathrm{v}$ případě sametové/ něžné revoluce se prosadilo narativů vícero a především se převrstvují, a tedy dodnes paralelně koexistují a soupeří. Různí lidé tak žili - a dosud žijí - vzájemně odlišné př́iběhy revoluce. Všechny tyto příběhy jsou nicméně lineární, mají svůj začátek, zápletku a vprostředku dění relativně otevřený konec. Své jednání pak lidé chápou jako součást svého příb̌hu revoluce. K účasti či neúčasti na revoluci a porevolučním vývoji je motivovala snaha napomoci tento př́běh v duchu preferované zápletky zakončit.

\section{Čtyři soupeřící narace aneb Kakofonie hlasů}

Narativ romance dle Krapfla vidí revoluci jako hrdinskou výpravu, jako boj dobra se zlem. Morálně ctnostní a nenásilní revolucionáři se v něm bez ohledu na následky heroicky obětují ve jménu vyšších cílů $\mathrm{v}$ podobě veřejného dobra. Jsou schopni konat zázraky, dotknout se čehosi transcendentního a proměňovat svět, společnost, mezilidské vztahy i sami sebe (nezamčená auta nikdo nevykrade, ztracené peněženky lidé vrací, kriminalita se během revoluce sniží o $75 \%$ ). V revoluci tak nejde jen o svržení režimu. Je příležitostí k očistě a znovuzrození jednotlivce i národního společenství a též k překonání násilností a chaotičnosti klasických revolucí. Tento narativ se zrodil 17. listopadu 1989 tváří v tvář obuškům na Národní třídě, ale okrajově přežívá dodnes.

Zatímco romance lid mobilizovala a požadovala radikální rozchod s minulostí, narativ vykládající revoluci jako komedii zkusili zkraje roku 1990 vyprávět pražští a bratislavští vůdci revoluce obávající se radikalizace, anarchie a ulice (kádrování na pracovištích, požadavky Slováků a Moravanů na sebeurčení, vlny stávek), kterou zkusili demobilizovat. Začali se proto vyhýbat pojmu „revoluce“. Podle nich již nešlo o střet dobra a zla, ale o konflikt zájmových skupin. Kompromis s představiteli minulého režimu je proto možný, koneckonců jsou to také lidé (komunisty obsazené Federální shromáždění zruší ústavní článek o vedoucí roli KŠČ, zvolí Havla prezidentem a kooptuje nekomunistické poslance). Všichni se mohou změnit, usmíření a začlenění komunistů do společnosti je projevem lidskosti. V další fázi revoluce se tak střetl narativ revolučních radikálů (romance) s narativem umírněných (komedie). Komediálním vyprávěním podporujícím status quo se zaštítila nová a pragmatická politická elita, které vyhovuje neaktivistické pojetí politického provozu. Podle nich nakonec vše dobře dopadlo, vrátili 
jsme se do západních struktur, prosperujeme a žijeme v nejlepším z možných světů. Idealisty, očekávající od revoluce více, lze ignorovat, jsou odtrženi od reality a jejich sny byly vždy iluzorní.

Revoluce vyprávěná jako tragédie přichází právě s touto kritickou sebereflexí. Upíná se stejně jako v romantickém pojetí k ideálům listopadu 1989, ale zároveň konstatuje, že „př́liš sametová" či „ukradená" revoluce nabrala neštastný směr a potřebuje korekci. Takto vyprávěný příběh nejprve upozorňoval, že za zásah policie ze 17. listopadu nebyl nikdo potrestán. Koordinační centrum pražského Občanského fóra (KC OF) i bratislavský Koordinační výbor Veřejnosti proti násilí (KV VPN) prý podobně jako KSČ rozhodují za zavřenými dveřmi a jsou odtržené od revolučních regionů. Ačkoliv hovoří o demokratizaci, trpí demokratickým deficitem a lid na okresech je pro ně jen kulisou. Podobně se kritizovala ekonomická transformace, bezvládí zneužitelné starými kádry k obohacování a měkkost ke komunistům a estébákům. Tragickou naraci vyprávějí třeba vítězové transformace, aktivističtí ne-politici, jako třeba iniciátoři výzvy Děkujeme, odejděte! (1999), studenti organizující Inventuru demokracie (2008-2014) i někteří politici (včetně Strany př́mé demokracie). Podle Krapfla se dnes vede nejostřejší spor právě mezi příznivci tragédie a komedie. Spor frustrovaných radikálů a mocí kooptovaných umírněných je sporem o povahu demokracie. Sporem o to, jakým způsobem by měla být moc realizována, nikoliv o to, koho namísto komunistů dosadit do pozic. Střetem principu demokracie s imperativem efektivní vlády. Jak se nechal slyšet jeden z revolučních studentů Václav Bartuška: „V dobách boje za demokracii není čas na demokracii." [s. 282] Proto pragmatici moci jako prezidenta prosadili Havla na úkor populárnějšího Alexandra Dubčeka, KC OF a VPN² ignorovaly okresy, došlo $\mathrm{k}$ posunu od pokusů o př́mou demokracii k té zastupitelské a Klaus s Mečiarem navzdory veřejnému mínění rozdělili Československo, aby poté navzdory sympatiím části veřejnosti k socialismu, jež se však během prvního roku revoluce postupně vytratily, ordinovali neoliberální reformy.

Jestliže se mocensky etablovali vypravěči komedie čas od času konfrontovaní narátory tragédie, ve veřejném diskurzu podle Krapfla sílí hlas ironické satiry. Př́běh proponentů starého režimu, ale třeba i disidenta, novináře a chartisty Jana Urbana podporuje občanskou lhostejnost a podrývá demokratickou politickou kulturu. Hovoří o tom, že k revoluci nedošlo, jednalo se o konspiraci StB. Nebo o tom, že revolucionáři selhali natolik fatálně, že k žádné revoluci nedošlo. Nebylo tak žádných hrdinů, vzepětí národa, změny k lepšímu ani šance cokoliv zlepšit. Narace romance i tragédie vzývající dobrou povahu člověka a potenciál společnosti sebe samu zlepšit je tak v cynické optice satiry zesměšňována.

\footnotetext{
${ }^{2}$ Od března 1990 se Koordinační výbor Veřejnosti proti násilí přejmenoval na Koordinační
} centrum Veřejnosti proti násilí. 


\section{Posvátné ideály aneb Na co se zapomnělo}

Druhou, na díle Emila Durkheima či René Girarda teoreticky založenou, originální a obecnější kapitolu „Sounáležitost, posvátnost, zrod symbolického vesmíru“ [s. 57-102] rozvíjí třetí a deskriptivnější kapitola s názvem „Ideály listopadu“ [s. 103-146]. Obě kapitoly pokládám za jádro sdělení knihy. Obě kapitoly přitom rozpracovávají naraci romance a na rozdíl od zbytku knihy vycházejí z rané euforické revoluční fáze charakterizované konsenzem revolucionářů. Východiskem je zde Krapflovi dvojitá diskontinuita: exploze dosud neexistující občanské společnosti a prosazení se diskurzu romance v kontrastu k dosavadnímu ironickému nastavení netečné a cynické veřejnosti.

V centru analýzy je durkheimovská teze o probuzení a následné sakralizaci společenství. Sametovou revoluci Krapfl rekonstruuje jako svátek („krásná horečka“, "zázrak", „pohádka“), jako pokus o odpoutání se od profánní každodennosti a dotyk s transcendentnem (pravdou, národem, posvátnými principy), kdy revolucionáři obnovují a rekonstruují pocit existence národního společenství a jeho sdílených hodnot. Revoluce je tedy událostí, kdy společnost rekonstituuje a oslavuje sebe samu. Během revoluce tak zdaleka nejde jen o soupeření se starým režimem, o prosazování požadavků, o manifestaci rozložení sil ve společnosti. V sebepojetí revolucionářù se nejedná pouze o revoluci politickou, ale morální. Cílem totiž není jen zpochybnění legitimity starého režimu a jeho svržení, ale položení posvátných základů pro oprávněnost režimu nového. A ten má stát na probuzeném či znovuzrozeném („rok nula“, „návrat z emigrace“), mravně očištěném (symbolika nevinných, nenásilných a mladých studentů) a nově definovaném národním společenství, orientovaném kolem posvátných principů listopadu 1989, a na sakralizaci obětí v podobě policií zbitých studentů na Národní tř́iě (spontánní vznik pietní svatyňky se svíčkami). Jak tuto představu ve své době vyjádřil Valtr Komárek, revoluce zrodila ",svatou emoci“, přičemž by bylo záhodno „založit na ní budoucí Československo“ [s. 59].

Lidé se mobilizují tváří $\mathrm{v}$ tvář zjevně slabému a ustupujícímu režimu proto, že cítí potřebu být $\mathrm{v}$ takto vypjaté a historicky zlomové době spolu s ostatními, potřebu solidarity a sdílení. Zároveň cítí zodpovědnost za vytvoření nového světa i člověka, revoluce je pro ně příležitostí manifestovat samotnou existenci a jednotu národního společenství (to zejména skrze generální stávku 27. listopadu, živé řetězy, spanilé jízdy studentů po republice, happeningy, masopusty) a znovu od základů promyslet a definovat jeho identitu. Revoluci revolucionáŕi chápou právě také jako příležitost stát se lepším člověkem („revoluce slušných lidí“). Vedle dosud nepoznaného pocitu společenství jim dává pouhá účast na revoluci také dosud nepoznaný pocit svobody, jak se vyjádřil revoluční student Tomáš Zábranský (10. 12. 1989): „Posledních několik týdnů v nás všech vyvolalo nový, do těch dob neznámý pocit. Pocit vlastenectví, sounáležitosti, hrdosti. Pocit podivného tlaku v očích při zpěvu hymny. Pocit opojení z nově nabyté, překvapující svobody. Jenže tato svoboda je prozatím dočasným stavem." [s. 95] 
Základem revolučního konsenzu se stalo pět posvátných ideálů listopadu 1989: nenásilí (požadavek adresovaný režimu i revolucionářům), lidskost (cílem je život beze strachu a důstojnost dosažená odmítnutím násilného principu, že lidé mají sloužit stranám, strojům či byrokratickým aparátům; společenský systém má sloužit lidem, ne opačně), sebeorganizace (hrdost na schopnost zorganizovat se spontánně a neformálně bez pomoci režimu, jenž dokáže lid organizovat jen s pomocí byrokracie a násilí), demokracie (smysluplná participace na rozhodování a permanentní zodpovídání se a odvolatelnost mocných na úrovni stávkových výborů, vedení podniků i centrální vlády; princip referenda a dialog o všem ostatním, na čem není shoda), spravedlivost (nerovnost sama není problém, jde o morálnost dosahování postavení; komunistická nomenklatura líčená jako „šlechta“ žijící v rozporu s ideologií KSČ). Centrální hodnoty revoluce se tak podle Krapfla netočily kolem hmotného blahobytu (to se dostalo do popředí později), ale kolem mezilidských vztahů. Tyto posvátné principy se měly stát vodítkem pro transformaci vědomí lidí a následně i jedinců a celé společnosti. Avšak revolucionáři se dokonce domnívali, že revoluce dává př́iležitost ke změně celému světu.

Posvátné principy - zakládající dogmata nového občanského náboženství - se podle Krapfla vyprofilovaly „zdola“. Nešlo tedy o překlopení ideálů intelektuálů disentu formulovaných před rokem 1989. Revoluce podobně neměla žádný zakládající a "shora“ vyhlášený dokument typu Deklarace práv člověka (Velká francouzská revoluce) nebo Deklarace nezávislosti (Americká revoluce). Nešlo ani o výraz již existující ideologie, revoluční dogma se stavělo nad politické ideologie a nad stranický princip. Ideály se tak dle autora vytvořily v reakci na události na Národní třídě 17. listopadu 1989. Snad i díky pozitivní orientaci na idealizovanou představu Západu, především ale s pomocí negativního sebevymezování se revolucionářů vůči režimu: my jsme dobří a čistí, režim je zlý a nebezpečný. Aby tak revolucionáři věděli, kdo jsou či chtějí být, museli si uvědomit, kdo nejsou a kým se rozhodně nechtějí stát.

Paradoxně ale podle Krapfla řada ideálů pocházela z repertoáru samotného režimu. Ten povědomí o revoluční tradici držel při životě s cílem zdůvodnit svou moc. Tato tradice se však během listopadu 1989 jako bumerang obrátila proti režimu. Občané marxismem cvičení k vyhledávání „rozporů“ v nekomunistických systémech je pak byli schopni nalézat i v tom komunistickém. Sametová revoluce pak ve svém sebepojetí mohla kontinuálně navazovat na sovětskou glasnoste a především na „obrodný proces“ $\mathrm{z}$ roku 1968. Absence konsenzu mezi pražskou centrálou OF (a bratislavským vedením VPN) a revolučním obyvatelstvem se týkala právě socialismu. Revolucionáři se pưvodně nebouřili proti socialismu. Tento ideál nechtěli zrušit, nýbrž naplnit (např́ílad diskuse tzv. švédského modelu). KSČ vytýkali, že socialismus deformovala. Šlo tak podle Krapfla o vzpouru lidu proti duchovním, kteří zradili svou doktrínu. A podobně jako běhen reformace před pěti sty lety, byly-li hradby ortodoxie již jednou nalomeny, původní volání po reformně se změnilo v revoluční požadavek alternativního systému. 


\section{Rozpad konsenzu aneb Odcizení revolučních elit}

Zbylé tři kapitoly již pojednávají o rozpadu konsenzu revolucionářů: o regionalismu a rozklížení federace, o konfliktu o pojetí demokracie a o odcizení Prahy a Bratislavy od revolucionářù, vedoucího k rozpadu revoluční koalice v podobě OF a VPN. Čtvrtá kapitola s názvem „Hranice sounáležitosti“ [s. 147-195] nabízí originální pohled na rozpad federace. Ten líčí jako nikoliv nutné vyústění revoluční dynamiky. Podle autora revoluce rozpoutala politický konflikt o to, kdo má právo mluvit jménem mobilizovaného a sakralizovaného společenství a reprezentovat ho tak směrem $\mathrm{k}$ představitelům starého režimu, k ostatním revolucionářům i občanům. Řada měst a poté i okresů, krajů a republik se bouří proti vyššímu celku ve jménu práva na sebeurčení. Tuto svou rebelii pokládají za pokračování revoluce. Zároveň však nižší jednotky ve svém rámci umlčují a tvrdí, že je reprezentují. To Krapfl identifikuje jako nedemokratický prvek demokratické revoluce, přičemž ukazuje, jak politické soupeření mezi revolucionáři kopíruje administrativní strukturu režimu. Shromáždění a manifestace dle autora nejprve posílily vědomí společenství na místní úrovni. Revoluce tak rozpoutala rivalitu mezi městy, lokální patriotismus (požadavky větších pravomocí samosprávám, památníky slavných rodáků, ambice zakládat vysoké školy) a regionalismus (proti pragocentrismu a bratislavocentrismu charakterizovanému prŕstupem "o nás bez nás" se vymezující Morava a východní Slovensko). Štěpení tedy podle Krapfla postupovalo od mikroúrovně, nakonec se však projevilo i na makroúrovni federace a vyústilo v rozpad Československa (požadavky Brna na emancipaci Moravanů nebyly úspěšné).

Nicméně právě na tomto místě je zapotřebí upozornit na nesoulad mezi slovenskou a anglickou verzí knihy na straně jedné a zde recenzovaným vydáním verze české na straně druhé. Text slovenského vydání Revolúcia s l’udskou toárou [Krapfl 2009] autor osobně dlouhé měsíce sám editoval a na základě ohlasů slovenského a českého publika poté připravil anglojazyčné a v mezinárodní vědecké komunitě oceňované ${ }^{3}$ vydání Revolution with a Human Face [Krapfl 2013]. Avšak české vydání oproti tomu nakladatel vydal i bez autorizace a přes nesouhlas autora, mezi oběma stranami proto běží právní spor. Vychází přitom především $\mathrm{z}$ anglojazyčné předlohy, takže občas dochází $\mathrm{k}$ významovým posunům například u citací původních českých či slovenských pramenů. Odlišnosti a posuny jsou přitom často jen $\mathrm{v}$ detailech, ale dobrý historik podle Krapfla klade důraz právě na přesnost $\mathrm{v}$ detailech. ${ }^{4}$ Největší interpretační posun se pak týká právě pasáží o štěpení, jež mohlo přispět k rozpadu federace. Revoluce totiž dala vzniknout dvěma protichưdným impulzům: impulzu $\mathrm{k}$ federativnosti a $\mathrm{k}$ „imperialis-

\footnotetext{
${ }^{3}$ Kniha dostala cenu Czechoslovak Studies Association Book Prize a poté také cenu George Blazyca Prize in East European Studies, udělovanou British Association for Slavonic and East European Studies.

${ }^{4}$ Emailová komunikace s Jamesem Krapflem, jaro a léto 2018.
} 
mu“. Sklon $\mathrm{k}$ federativnosti se projevil zejména při sdružování na místní úrovni, ale také za účelem koordinace mezi městy nebo okresy, případně dokonce i na regionální úrovni (Morava, východní Slovensko). Podle podobné logiky se nicméně organizovali také odboráři dané profese, a to např́ič Československem. Tyto spontánně vznikající sítě mezi lidmi fungovaly na principu rovnosti a kopírovaly již existující kanály komunikace. Protikladný imperiální impulz naopak stojí na touze řídit druhé - spíše než se s nimi koordinovat -, kteří navíc nejsou přijímáni jako rovnocenní.

Otázka národní identity byla každopádně stěžejní od počátku revoluce, jak ukazuje romantická narace. Nedebatovala se však na půdorysu nacionalismu etnického, nýbrž občanského, který počítal s inkluzí všech, včetně Madarů. Národ byl tehdy synonymem shromážděného lidu na náměstích, synonymem revolučního společenství. Etnický nacionalismus tak kanalizoval nahromaděnou energii mobilizovaného lidu až ve druhé fázi revoluce, kdy se prosadil. Všude sdíleným symbolem se totiž zprvu stal Čechoslovák Masaryk odkazující na prvorepublikové Československo, obliba „českého“ Havla a "slovenského“ Dubčeka byla též rozložena rovnoměrně $\mathrm{v}$ obou částech federace. Nicméně s etnickým nacionalismem pracovala část slovenského exilu snažícího se navázat na Slovenský stát (1939-1945) a odkazujícího se na Josefa Tisa. Podobně chápali revoluci jako logickou cestu k nezávislosti Slovenska někteří občané severu Středoslovenského kraje. Posílení dosud okrajových nacionalistů však přinesla především tříměsíční a ubíjející „ppomlčková válka“ (odstartovaná 29. ledna 1990 návrhem Václava Havla na změnu názvu státu). Této situace podle Krapfla také využily „,staré struktury“, které tak odvedly pozornost od otázek vyrovnávání se s minulostí, jež by je mohly ohrozit.

Klíčové však dle Krapfla bylo, že bratislavský KV VPN zdůrazňoval slovenskou národní odlišnost až nacionalismus hned od počátku. Pasoval se totiž do role reprezentanta všech revoluci podporujících Slováků, aby mocensky posílil vůči zbytku Slovenska i vůči Praze. A pražské KC OF na tuto hru přistoupilo. Nevědělo - a ani nechtělo vědět - "podrobnosti“ o dění na Slovensku, ostatně stejně jako o dění v českých okresech, takže bylo závislé na informacích od KV VPN. KC OF a KV VPN se tak vzájemně uznaly jako zástupci dvou národů a slíbily si nevměšování do svých republikových záležitostí (29. listopadu 1989). Rozdělily si tedy zemi, aniž by se pokusily o federativní přistup a sdílení moci na centrální úrovni, aniž by tento krok konzultovaly s okresními pobočkami a braly na ně ohledy. Nepokusily se ani o vybudování společného československého hnutí $z$ dola a potlačily ho tam, kde takové hnutí centrované na federativnost spontánně vzniklo (východní Slovensko). Mocenský konflikt se tak neodehrával mezi Prahou a Bratislavou, ale mezi Bratislavou a zbytkem Slovenska. KV VPN totiž nutil slovenské pobočky OF (dominovaly v 21 z 38 okresů a ve vedení dvou ze tří krajů) k začlenění pod Bratislavou vedenou VPN (probíhalo do začátku 1990). Podstatná část slovenských revolucionářů orientovaných na Prahu a myšlenku federace tak byla podle Krapfla frustrovaná: ačkoliv ku Praze a federaci vzhlížela, byla jí odvržená (byli lépe informováni o dění v Praze než Bratislavě, po vzoru Prahy 
zakládají OF, delegace do Prahy). A rozparcelování revolucionářů na pražské OF a bratislavskou VPN pak podle Krapfla vytvořilo cestu k snazšímu rozparcelování federace na Česko a Slovensko.

Pátá kapitola „Moc v ulicích“ [s. 196-232] se soustředí na snahu revolucionáŕů „zdola“ prosazovat radikální pojetí přímé demokracie a na úsilí tuto iniciativu „shora“ brzdit. Moc i autorita podle Krapfla ležela během prvních dvou revolučních měsíců doslova na ulici. Sametová revoluce tak podle něj nebyla koordinovaným předáním moci, ale revoluční změnou vynucenou mobilizací lidu, jakkoliv nakonec proběhla nenásilně a v mezích ústavnosti. Pro Krapfla je však typické, že ho ani tak nezajímají tyto události v Praze, ale opět stopuje podstatu dění na lokální úrovni. A tam lidé v ulicích chápali princip demokracie a nenásilí jako cestu k obnově svého společenství. Pikantní přitom je, že na základě rad studentů právnických fakult začali měnit vedení podniků (asi 20 \% vedení vyměněno), státních úřadů (národních výborů všech úrovní), škol (k nejrychlejším změnám došlo na univerzitách zřizujících samosprávy z akademiků i studentů, vítajících profesory vyhozené po roce 1968, rušících přednášky z marxismu-leninismu a vyhazujících komunistické kádry) a odborů (týkalo se 95 \% odborových organizací) v rámci platných zákonů, které však komunistický režim nerespektoval a neuváděl do praxe. Kromě personálních změn revolucionáři tlačili také na regionální redakce, aby nedávaly hlas pouze režimu, předávali veřejným institucím majetky KSČ, měnili názvy ulic a symboly ve veřejném prostoru. Získávali tak bezprecedentní - nikdy předtím ani poté nepoznaný - vliv na veřejné dění, což jim dávalo pocit zplnomocnění.

Nositelem moci i autority na lokální úrovni přitom byly místní skupiny OF/VPN. Chápaly se jako inkluzivní a nadstraničtí (či nestraničtí) reprezentanti vůle lidu, kterou zjištóvaly a poté vyjednáváním a nátlakem vymáhaly. Místní pobočky OF/VPN tak fungovaly jako obdoba revolučních „rad“ známých i z jiných revolucí. Jejich moc vyplývala z toho, že se situovaly do centra sociálních sítí: zprostředkovávaly vztah mezi veřejností, reprezentanty režimu a pobočkami OF/VPN. Odpor přicházel od komunistických funkcionářù (zejména ředitelů podniků), ale také od pražského vedení revoluce, které se obávalo excesů přímé demokracie (požadavek odvolat funkcionáře kdykoliv ztratí důvěru). Strach $\mathrm{z}$ režimu vystřídal v očích představitelů, jako byl Pithart, strach z revolucionářů. Mezníkem je zde Krapflovi Pithartův televizní projev z 19. ledna 1990, varující před přebíráním komunistických kádrovacích praktik a vyřizováním účtů; ne každý v OF měl být automaticky dobrý a každý v KSČ špatný, oba tábory mají kariéristy.

Poslední kapitola „Vůle lidu“ [s. 233-268] pojednává o rozpadu revoluční koalice sdružené pod hlavičkou OF, resp. VPN. Výsledkem je transformace hnutí v politickou stranu, aktivistického důrazu na přímou demokracii v důraz na zastupitelskou demokracii, přechod od mobilizace občanů v jejich demobilizaci. Kořenem sporu je - i v dalších kapitolách tematizované - rostoucí napětí mezi centrálami obou organizací a pobočkami v regionech frustrovanými z demokra- 
tického deficitu, jakkoliv k odcizení mohla přispět i dominance technické inteligence na okresech a té kulturní na ústředí. Neexistoval předně mechanismus, jakým ústředí přebíralo náměty a připomínky z okresů. Praktikovala se „kabinetní politika" zavřených dveř́í, které dominovala parta lidí z Prahy a Bratislavy. První celorepublikový sněm OF se konal až 23. prosince 1989, účastnilo se ho ale málo delegátů (92), přičemž dvě třetiny z nich nakonec tvořili Pražané (čtvrtého republikového sněmu v únoru 1990 se naopak pražští delegáti arogantně vưbec neúčastnili, zřejmě to pokládali za ztrátu času). Sněm VPN byl zorganizován až 27. ledna 1990 a k demokratickému deficitu vedl opak: delegátů byla tisícovka, smysluplná diskuse nebyla možná. Revolucionáře na okresech poté nadzvedlo, když centrály bez konzultací přijaly nový volební zákon a v duchu praxe KSČ pak direktivně rozepsaly kandidátky do voleb $\mathrm{v}$ regionech, kterým $\mathrm{v}$ podstatě vnutily zde cizí (např́íklad Petr Pithart nebo Dagmar Burešová kandidující na jižní Moravě), nebo dokonce zcela neznámé kandidáty z pražské a bratislavské party, čímž je po celé republice zvýhodnila. Vrcholem všeho byla následná kumulace poslaneckých a ministerských funkcí těmito lidmi a to, že si čerstvě zvolené Federální shromáždění a vláda naordinovaly letní prázdniny (1990). Klíčové reformy stály a lidé pocitovali nejistotu stran dalšího vývoje. Občanské fórum a VPN se na přelomu let 1990 a 1991 rozpadly díky zakladatelům ODS a později HZDS. Ti využili frustrace poboček OF a VPN v regionech, začlenili je do svých stran a díky doznívajícímu aktivismu a revolučnímu nadšení drtivě zvítězili v následujících volbách (1992). Jakmile se však takto dostali k moci, začali radikálně demokratický a aktivistický étos s odkazem na mandát od voličů krotit, přičemž navzdory veřejnému mínění prosadili rozdělení federace.

\section{Recepce, hodnocení, impulzy}

Krapfl předložil zdola ložený příběh sametové revoluce, který nutně nevyvrací, ale přinejmenším komplementárně doplňuje revoluční přiběh viděný perspektivou pražských a bratislavských elit, jejž předložil český historik Jiř́ Suk. Krapflưv příěh přitom rozbíjí oficiální naraci, když křísí kakofonii polozapomenutých hlasů, leckoho proto může provokovat. Jde navíc o pohled distancovaného outsidera, který se během dlouhodobých badatelských pobytů naučil česky, slovensky a mad’arsky a pronikl do zdejší kultury, ale v dění není zaangažován. Mủže si proto dovolit kritický nadhled a má také šanci uvidět jevy, vưči kterým insider ztrácí citlivost. V tomto smyslu je pokračovatelem amerického historického sociologa Charlese Tillyho, který svá monumentální studia revolucí odstartoval ve Francii [Tilly 1964, 1978, 1982]. Anebo francouzského aristokrata Alexise de Tocquevilla, který se naopak vydal opačným směrem studovat revoluci americkou [de Tocqueville 1835, česky 2000].

Tento pohled outsidera přitom zaujal, hodnocen je většinou jako průlomový právě pro forsírování hlasů zdola. Již české recepce slovenského vydání knihy (2009) byly mezi historiky i publicisty pochvalné. Levicoví novináři Jaroslav Fiala 
a Lukáš Rychetský [2014] hovoří o aroganci historické paměti, když zmizel př́íběh těch, kteří revoluci reálně provedli. Hlas slabších je tak podle nich i v tomto případě zatlačován. Podle nich jsou sice revoluce často vykládány jako důsledek vzedmutých frustrací, nicméně samy mohou vysoká očekávání - a následně také vysoké frustrace - zrodit, nenaplní-li se jejich prŕslib. Také novinář Patrik Eichler [2010] pozitivně hodnotí, že Krapfl překračuje rámce tzv. velké politiky implikující nedůležitost účasti lidí na revoluci, a pozastavuje se právě nad kontrastem mezi rozsáhlou dobovou aktivizací lidu a později se etablující elitní intepretací Listopadu. Publicista Adam Votruba [2015] navíc zdůrazňuje, že větší zapojení okresů mohlo vést $\mathrm{k}$ demokratičtější polistopadové společnosti. Historik Vítězslav Sommer [2011: 297] v tomto duchu hovoří o tom, že Krapfl „staví ,sametovou revoluci` zpět z hlavy na nohy a dává zaznít myšlenkám, které se možná jeví jako př́iliš idealistické a naivní, jež však dávaly dynamiku výrazným změnám, k nimž na konci roku 1989 došlo“. S úplně první akademickou reflexí slovenského vydání knihy u nás nicméně přišel autor z nejpovolanějších, historik Jiří Suk [2010] a poté Miloš Řezník [2011]. Výborné shrnutí Krapflovy knihy přinesla také historička Adéla Gjuričová [2013]. Vyzdvihuje geertzovský přístup snažící se o rekonstrukci „pavučin významů“, ve kterých jsou lidé jakožto jednající aktéři zavěšeni, přičemž bývají děje spoluformovány právě tím, jaké významy se během nich rozvinou. Jako jedna z mála vznáší i pochybnost týkající se autentičnosti zhruba čtyřiceti českých, moravských a slovenských regionálních archívů, o které se Krapfl opírá. Jejich budování totiž mohlo být také „revolučním aktem“, jistou stylizací revolucionářù. Domnívám se, že kromě řady autorových osobních vazeb na české akademiky, mohl k příznivé recepci díla přispět také rostoucí zájem českých badatelů o problematiku paměti. Reflexe slovenského, anglojazyčného a poté i českého vydání knihy mezi českými sociology nicméně dosud absentuje, což naznačuje, že bytostně sociologickou tematiku revolucí přenechali právě historikům.

Krapfl explicitně navazuje na Lynn Huntovou a její klasickou analýzu Velké francouzské revoluce. V současnosti je Krapflovi na poli sociologie patrně nejblíže kulturní sociolog Jeffrey C. Alexander, který v esejistické knize Performative Revolution in Egypt podal naraci egyptských revolucionářů i režimu [2011]. Oba totiž ve studiích revolucí reprezentují paradigmatický obrat zájmu od struktury ke kultuře [srov. Foran 1997; Černý 2016]. Ostatně jestliže Krapfl identifikuje krystalizaci dvou nejposvátnějších principů sametové revoluce - nenásilí a lidskou důstojnost - tyto ideály podle zjištění autora recenzního eseje také zprvu stály v centru egyptské revoluční narace vyprávěné na způsob romance, a to vedle dủrazu na sebeorganizaci, demokracii (dialog) a patriotismus. Podobně se v obou př́padech stalo, že řadu ideálů nadstranicky a nadideologicky orientovaní revolucionáři převzali z diskurzivního repertoáru režimu a obrátili je proti němu [srov. Černý 2017].

Jakkoliv je Krapflova práce idiografická a zaměřená na detailní rozbor specifik jedné revoluce, nabízí impulzy pro komparativní studium revolucí a revo- 
lučních diskurzů. Existuje vzorec, kdy na začátku revoluční narace vždy tenduje k romanci s cílem mobilizovat lid proti starému režimu, poté se o slovo hlásí komedie a tragédie, když po svržení starého režimu radikálové a umírnění v rámci rozpadající se revoluční koalice začnou zápasit o moc mezi sebou navzájem, aby se nakonec ke slovu dostala i satira, když se přeskupení zastánci starého režimu pokouší revoluci zdiskreditovat a nahlodat tak legitimitu porevolučního uspořádání? Nereprezentuje tento vzorec weberovský cyklus, kdy je tradiční či právně-racionální autorita čas od času vyzvána na souboj z podstaty revoluční autoritou charismatickou, která je však krátkodechá a dřive či později opět přechází v autoritu tradiční či právně-racionální? Šlo by jednotlivé narativy reprezentované různými revolučními aktéry propojit s koncepty fází revolučního cyklu, se kterými operují autoři jako Pitirim Sorokin, Crane Brinton či Jaroslav Krejčí? Aby byl porevoluční režim směrem ke svým občanům i sousedním zemím nenásilný a rezignoval na snahy revoluci exportovat, musí vzniknout nenásilně, jinak nedokáže uniknout svému krvavému zrodu (path-dependency)? Není namísto socioekonomické či politické frustrace $\mathrm{z}$ nenaplněných očekávání $\mathrm{v}$ optice sociálně-psychologických přístupů Jamese Daviese či Teda Gurra neméně důležitou př́íčinou revolucí frustrace mravní, kdy starý režim přestane vyhovovat morálním nárokům obyvatelstva (jak Jaroslav Krejčí dokládá nejen na případu husitské revoluce)?

Krapflově kulturně-historické analýze by prospělo, pokud by se podobně intenzivně zabýval také rozborem režimní narace. Mohl by pak ukázat, zda a jak spolu revolucionáři a režim diskurzivně soupeřili a do jaké míry tím své antagonistické diskurzy formovali. Jeho kulturně-historická metoda orientovaná na studium dokumentů pak zřejmě selhává při zohlednění možná nejpočetnější skupiny obyvatelstva, a to „šedé zóny“ těch, kteří se neidentifikovali ani s režimem, ani $\mathrm{s}$ revolucionáři, setrvávali $\mathrm{v}$ pasivitě a rozhodli se nejednat. Pokud si autor klade za cíl vzkřísit polozapomenuté hlasy a rozbít monopolní revoluční naraci, bylo by vhodné se o něco podobného pokusit, zřejmě metodou orální historie. ${ }^{5}$

Za slabinu pokládám také absenci definice revoluce, klíčového termínu práce. Krapfl to na začátku knihy obchází šalamounským konstatováním, že šlo o revoluci, pokud to tak chápali samotní aktéŕi [s. 30]. Ponecháme-li stranou fakt, že bychom tímto způsobem vyřešili problém terorismu, protože teroristé sami sebe zpravidla za teroristy nepokládají, nebyly například egyptské vojenské převraty $(1952,2013)$ nutně revolucemi jen proto, že je za ně armádní propaganda vydávala a nemalá část mobilizované veřejnosti je také takto pochopila. Nejde

\footnotetext{
${ }^{5}$ James Krapfl se však domnívá, že jeho analýza postihuje myšlenky a touhy většiny obyvatel. Dovozuje to z toho, že se údajně až 75 \% zaměstnancủ zúčastnilo generální stávky (přerušením práce nebo symbolicky), prohlášení pracovních kolektivů podle dobrovolníků KV VPN podepsala většina zaměstnanců a až polovina občanů se pak na přelomu roku 1989 a 1990 angažovala v OF či VPN. Nicméně cílem práce nebylo analyzovat všechny společenské segmenty, ale hlavního aktéra revoluce, za kterého pokládá revoluční občany [emailová komunikace s Jamesem Krapflem, 7. června, 2018].
} 
o hnidopišství. Východoevropské případy (vyjma Rumunska) nabízejí podněty k revizím definice, jelikož jsou oproti předchozím revolucím specifické absencí násilí, pokládaného za definiční znak. Absence definice navíc brání obhájit relativně krátký časový rámec studie (zde 1989-1991). Problém časového vymezení ostatně dost možná opět otevře sám Krapfl, který se poslední dobou osvědčenou kulturně-historickou optikou pokouší zrekonstruovat události pražského jara (1968). Sametová revoluce jím tak nakonec může být pochopena jako součást dlouhodobého historického pokusu československé společnosti rekonstituovat sebe samu započatého, a poté přerušeného, právě v šedesátých letech 20. století, kdy se obě společenská vzedmutí upínala k týmž posvátným hodnotám a k témuž posvátnému společenství.

Karel Černý

\section{Literatura}

Alexander, J. C. 2011. Performative Revolution in Egypt: An Essay in Cultural Power. New York: Bloomsbury Academic.

Černý, K. 2016. „Staré a nové teorie revoluce: deset perspektiv.“ AUC Philosophica et Historica 2 (Studia sociologica XXI, Sociologie na hranicích: tradiční a rozvíjející se témata v dnešní sociologii): 73-96.

Černý, K. 2017. „Diskurz egyptské Revoluce 25. ledna: Perspektiva facebookové generace." Mezinárodní vztahy 52 (4): 5-32.

Eichler, P. 2010. „Když zemi vládne lid.“ Kulturní noviny [online] jaro/léto 2010: 5. Dostupné z: https://www.kulturni-noviny.cz/download/archiv/tiskem/2010/ jaro-leto-2010/4f6e59e4db0e0.

Fiala, J., L. Rychetský. 2014. „Zrazená revoluce.“ A2alarm.cz [online] 17. 11. 2014. Dostupné z: https://a2larm.cz/2014/11/zrazena-revoluce-1989/.

Foran, J. 1997. „Discourses and Social Forces: The Role of Culture and Cultural Studies in Understanding Revolutions." Pp. 203-226 in J. Foran (ed.). Theorizing Revolutions. London: Routledge.

Frye, N. 2003. Anatomie kritiky: čtyři eseje. Brno: Host.

Gjuričová, A. 2013. „Něžná historie. Kulturní historik v archivu." Soudobé dějiny 20 (3): 445-448.

Huntová, L. 2007. Francouzská revoluce. Politika, kultura, tř́da. Brno: CDK.

Krapfl, J. 2009. Revolúcia s l’udskou tvárou. Politika, kultura a spoločenstvo v Československu po 17. novembri 1989. Bratislava: Kalligram.

Krapfl, J. 2013. Revolution with a Human Face. Politics, Culture, and Community in Czechoslovakia, 1989-1992. Ithaca: Cornell University Press.

Krapfl, J. 2016. Revoluce s lidskou tváří. Politika, kultura a společenství v Československu v letech 1989-1992. Praha: Rybka Publishers.

Řezník, M. 2011. „James Krapfl: Revolúcia s ludskou tvárou. Politika, kultúra a spoločenstvo v Československu po 17. novembri 1989.“ Knižní recenze. Bohemia. Zeitschrift für Geschichte und Kultur der Böhmischen Länder 51 (1): 319-322, https://dx.doi.org/10.18447/BoZ-2011-1787.

Sommer, V. 2011. „Krapfl, James: Revolúcia s ludskou tvárou. Politika, kultúra a spoločenstvo v Československu po 17. novembri 1989.“ Knižní recenze. Securitas imperii 18 (01): 294-298. 
Suk, J. 2003. Labyrintem revoluce: Aktéři, zápletky a křižovatky jedné politické krize (od listopadu 1989 do června 1990). Praha: Prostor.

Suk, J. 2010. „KRAPFL, James: Revolúcia s ludskou tvárou. Politika, kultúra a spoločenstvo v Československu po 17. novembri 1989.“ Knižní recenze. Střed. Časopis pro mezioborová studia střední Evropy 19. a 20. století 2/2010: 166-171.

Tilly, Ch. 1964. The Vendée. New York: Harvard University Press.

Tilly, Ch. 1978. From Mobilization to Revolution. Ann Arbor: University of Michigan.

Tilly, Ch. 1986. The Contentious French. New York: Harvard University Press.

Tocqueville, A. de. 2000. Demokracie v Americe. Praha: Academia.

Votruba, A. 2015. „Revolúcia s lúudskou tvárou.“ Deník Referendum [online], 27. 3. 2015 [cit. 28. 7. 2018]. Dostupné z:

http://denikreferendum.cz/clanek/20078-revolucia-s-ludskou-tvarou. 